\section{Alih Kode dan Campur Kode Bahasa Arab}

(Studi kasus percakapan whatsapp mahasiswa Fakultas SAINTEK UIN MALIKI Malang)

\author{
Mubasyiroh \\ Pusat Pengembangan Bahasa, \\ UIN Maulana Malik Ibrahim Malang \\ mubasyiroh9@gmail.com
}

\title{
ABSTRAK
}

\begin{abstract}
Kajian penelitian ini adalah berfokus pada mendeskripsikan bentuk alih kode dan campur kode pada percakapan Bahasa Arab di grup whatsapp mahasiswa PKPBA fakultas SAINTEK UIN MALIKI Malang. Selanjutnya penelitian ini bertujuan untuk mendeskripsikan faktor-faktor yang mempengaruhi alih kode dan campur kode dalam percakapan Bahasa Arab di grup whatsapp. penelitian ini berjenis kualitatif dengan teknik pengumpulan data dengan cara analisis. Sedangkan data bersifat deskriptif. Dari penelitan ini dihasilkan temuan bahwa: 1) bentuk alih kode meliputi dua hal. Dilihat dari segi: a) bahasa yang digunakan untuk berkomunikasi, ditemukan bentuk alih kode yang meliputi: formal "bahasa sesuai dengan kaidah bahasa arab" dan informal "bahasa yang tidak sesuai kaidah Bahasa Arab”. Dilihat dari segi: b) hubungan antar bahasa, terdapat bentuk alih kode yang meliputi: bahasa Arab ke bahasa Indonesia dan bahasa Indonesia ditulis dalam kata arab atau pegon. 2) Bentuk campur kode meliputi dua sisi. Dilihat dari segi: a) unsur sintaksis, ditemukan bentuk campur kode yang meliputi: kata dan frasa. Sedangkan dilihat dari segi: b) kategorisasi kata, ditemukan bentuk campur kode yang meliputi: numeralia, pronominal, preposisi, nomina, verba, adjektiva dan adverbial. 3) Faktor-faktor alih kode dan campur kode meliputi: a) hubungan penutur dengan mitra tutur, b) perubahan situasi dari formal ke informal atau kebalikannya. c) perubahan topik pembicaraan. d) latar belakang Pendidikan dan tingkat kemampuan.
\end{abstract}

Kata kunci: Alih kode; campur kode; Bahasa Arab

\section{PENDAHULUAN}

Bahasa berfungsi sebagai alat berkomunikasi dalam kehidupan bermasyarakat. Adapun urgensi Bahasa adalah untuk memenuhi salah satu kebutuhan sosial manusia, yang mampu menghubungkan manusia satu dengan manusia lain di dalam berbagai peristiwa sosial tertentu.

Di era modern ini Mahasiswa berada pada zaman millenial yang teridentifikasi pada kesehariannya tidak bisa lepas dari smart-phone, mayoritas mereka memanfaatkan dari sisi positifnya, diantaranya dengan membuat grup whatsapp dalam komunikasi mereka dengan tujuan mempermudah pembelajaran. Hal tersebut juga didapati pada mahasiswa fakultas SAINTEK UIN MALIKI Malang, dalam percakapan mereka sering menggunakan dwibahasa walaupun mereka sudah berkomiten untuk berkomunikasi dalam Bahasa arab sebagai Bahasa keseharian dalam kelas dan dalam grup whatsapp mereka untuk mempercepat target pembelajaran karena mereka sebenarnya adalah dwibahasawan. Dikatakan dwibahasawan karena mereka mampu menguasai dua Bahasa atau lebih, mereka orang indonesia akan mampu berkomunikasi Bahasa jawa sebagai mother of language (lughotul umm) dan Bahasa Indonesia sebagai Bahasa Nasional, juga mampu menguasai Bahasa Arab atau Bahasa Inggris atau bahasa yang lain sebagai kosentrasi keilmuan mereka. Azhar, dkk menjelaskan bahwa, "

Kedwibahasaan berkaitan erat dengan pemakaian dua bahasa atau lebih oleh seorang dwibahasawan atau masyarakat dwibahasa secara bergantian" (Azhar, dkk. 2011: 9). Nah ketika mereka berkomukasi inilah muncul Fenomena dwibahasa yang dapat terjadi kapan saja dan dimana saja mereka berada. Fenomena yang dimaksud berkaitan dengan alih kode (code switching) dan campur kode (code mixing) Bahasa arab yang merupakan kosentrasi permasalahan dalam penelitian kali ini.

Mahasiswa fakultas SAINTEK UIN MALIKI Malang berasal dari berbagai macam latar belakang pendidikan yang berbeda, diantaranya mereka tinggal dipondok pesantren yang terintegrasi dengan sekolah formal dan sebagian diantaranya ada yang hanya menempuh Pendidikan formal saja, inilah 
yang menjadi perbedaan kemampuan yng dimiliki mahasiswa khususnya dalam berketrampilan berbahasa Arab mereka secara aktif (berbicara atau berkomukasi). Permasalahan ini tidaklah mudah bagi para penutur non-Arab. Selain problem intern pada Bahasa Arab yang memang berbeda dengan Bahasa Indonesia, kesulitan juga dikarenakan faktor ekstern di atas.

munculnya alih kode dan campur kode pada mereka karena mereka dalam proses belajar Bahasa arab, yang mana program ini diwajibkan kepada seluruh mahasiswa pada semester satu dan semester dua dengan harapan UIN MALIKI Malang mampu mencetak generasi yang unggul dengan minimal menguasi dua Bahasa asing yaitu arab dan Inggris sehingga membantunya dalam mengenal agama, budaya dan identitas kepribadiannya serta pengembangan keilmuan mereka.

Pembelajaran Bahasa Arab sama halnya dengan pembelajaran bahasa yang lainnya. Konsistensi, inovasi dan kreatifitas harus tetap dikembangkan. Sehingga, pembelajaran Bahasa Arab akan tetap eksis sesuai dengan perkembangan zaman. Keberadaan media sosial yang ada menjadi alat komunikasi alternatif yang dapat dimanfaatkan bagi para dosen dalam pembelajaran. Dengan menggunakan media komunikasi yang sudah familiar di kalangan mahasiswa, maka tidak akan ada alasan bahwa belajar Bahasa Arab itu sulit.

Meskipun demikian, banyak mahasiswa yang baru belajar Bahasa Arab mengalami kesulitan dalam percakapan mereka, problem ini yang harus diselesaikan dengan membiasakan mahasiswa berbicara Bahasa Arab melalui grup Whatsapp. Kegiatan berkomunikasi secara grup atau berkelompok dengan menggunakan fasilitas aplikasi yang ada di smart phone mereka, maka akan memposisikan mahasiswa untuk ikut aktif berkomunikasi secara berkala. Apabila hal tersebut dilakukan secara intens, maka tanpa disadari dan tanpa paksaan, mahasiswa akan menyampaikan pendapatnya di dalam grup Whatsapp mereka.

Adapun Penelitian-penelitian yang terkait dengan media whatsapp telah banyak dikaji, baik yang terkait dengan pembelajaran Bahasa Arab ataupun yang terkait dengan pembelajaran pada umumnya. Diantaranya adalah penelitian yang dibahas oleh Kartikawati, tentang media whatsapp pada tahun 2017. Penelitian tersebut menggunakan kelompok eksperimen dan kelompok control. Penelitian ini berfokus pada ada atau tidaknya pengaruh implementasi metode GI (Group Investigation) dengan WhatsApp Messenger sebagai mobile learning terhadap kemampuan berpikir kritis peserta didik. Dalam penelitian tersebut menjelaskan, bahwa kemampuan berpikir kritis pada kelompok eksperimen lebih baik daripada pada kelompok control. (Kartikawati, dkk, 2017: 33-38).

penelitian yang dibahas oleh Edi Suryadi, dkk tentang pengaruh whatsapp pada kedisiplinan peserta didik dalam belajar mata pelajaran Pendidikan Agama Islam di SMK Analis Kimia YKPI Kota Bogor. Penelitian ini dilatarbelakangi adanya penggunaan whatsapp yang intens di kalangan para siswa di sekolah tersebut tahun 2016/2017, sehingga yang ingin diketahui oleh peneliti adalah tingkat kedisiplinan siswa dalam belajar. Hasil dari penelitian ini adalah whatsapp memberikan pengaruh yang kuat terhadap siswa untuk belajar mata pelajaran Pendidikan Agama Islam, yaitu dikarenakan mayoritas siswa memakai whatsapp ketika pembelajaran, sehingga fokus dan kedisipinan siswa melemah. (Suryadi, dkk, 2018:1-20)

Penelitian Adi Nugroho pada tahun 2011 tentang alih kode dan campur kode pada komunikasi gurusiswa di sma negeri 1 wonosari klaten. Dan faktor-faktor yang mempengaruhi alih kode dan campur kode. Data penelitian diperoleh dengan teknik simak, catat, dan rekam. Data penelitian dianalisis dengan menggunakan teknik analisis deskriptif kualitatif. Adapun Hasil penelitian bentuk alih kode meliputi dua sektor yaitu bahasa yang meliputi: bahasa formal dan informal. Sedangkan dari segi hubungan antarbahasa, meliputi: bahasa Prancis - bahasa Indonesia dan bahasa Indonesia - bahasa Prancis. Bentuk campur kode guru pun meliputi dua sektor yaitu unsur sintaksis, meliputi: kata dan frasa dan kategorisasi kata, meliputi: nomina, verba, adjektiva, adverbia, numeralia, pronomina, dan preposisi. Faktor-faktor alih kode dan campur kode meliputi: hubungan penutur dengan mitra tutur hadirnya pihak ketiga, perubahan situasi dari formal ke informal atau sebaliknya, dan perubahan topik pembicaraan (Nugroho, 2011).

Penelitian Siti Rohmani, dkk pada tahun 2013, yang membahas tentang analisis alih kode dan campur kode pada novel negeri 5 menara karya ahmad fuadi. Penelitian ini mendeskripsikan bentuk alih kode dan campur kode, serta faktor penyebab alih kode dan campur kode, dan fungsi alih kode dan campur kode novel Negeri 5 Menara karya Ahmad Fuadi. Penelitian ini merupakan penelitian deskriptif 
kualitatif dengan sampel percakapan pada novel Negeri 5 Menara karya Ahmad Fuadi. Teknik sampling yang digunakan adalah teknik purposif. Teknik pengumpulan data yang digunakan adalah analisis dokumen. Hasil penelitian ini adalah Pertama, gejala alih kode terjalin dalam empat formasi. Gejala campur kode terjalin dalam tujuh formasi. Kedua, faktor pendorong alih kode berkaitan dengan pembicara dan pribadi pembicara, mitra tutur, fungsi dan tujuan pembicaraan, dan situasi pembicaraan Faktor pendukung meliputi alih kode extralinguistic dan intralinguistik. Faktor extralinguistic berkaitan dengan karakteristik speaker seperti latar belakang sosial, religiusitas perasaan, tingkat pendidikan, dan lokalitas perasaan. Faktor Intralinguistics berkaitan dengan adanya kata-kata dalam bahasa yang dapat menampung konsep makna yang dimaksudkan dalam elemen linguistik dimasukkan. Ketiga, fungsi alih kode dan campur kode novel Negeri 5 Menara karya Ahmad Fuadi adalah untuk menjelaskan, memerintah, berdoa, bertanya, dan menegaskan maksud. (Rohmani, dkk: 2013)

Dari berbagai penelitian yang diperoleh dari keterangan diatas bahwa whatsapp dan media social dapat dipergunakan di dalam proses pembelajaran atau di luar pembelajaran. Dari uraian tersebut, dapat dirumuskan permasalahan yang akan dikaji dalam penelitian ini. Permasalahan tersebut berkaitan dengan bagaimanakah wujud alih kode dan campur kode bahasa arab Studi kasus percakapan whatsapp mahasiswa fakultas SAINTEK UIN MALIKI Malang. dan faktor-faktor yang melatarbelakangi terjadinya gejala kebahasaan tersebut. Berdasarkan permasalahan tersebut tujuan penelitian ini adalah mengetahui wujud alih kode dan campur kode bahasa arab Studi kasus percakapan whatsapp mahasiswa fakultas SAINTEK UIN MALIKI Malang. dan mengetahui faktorfaktor yang melatarbelakangi terjadinya gejala kebahasaan tersebut.yang kesemuanya merupakan bidang kajian Sosiolinguistik. penelitian ini berjenis kualitatif dengan teknik pengumpulan data dengan cara analisis. Sedangkan data bersifat deskriptif.

Individu yang tidak menguasai bahasa yang digunakan oleh masyarakat setempat atau dalam grup whatsapp contohnya tentu akan merasakan kesulitan berkomunikasi dan mengintegrasikan diri dalam masyarakat tersebut. Hal tersebut sesuai dengan definisi bahasa menurut KBBI (2005:67) yang menyatakan bahwa, "Bahasa adalah sistem lambang bunyi yang arbitrer, yang dipergunakan oleh para anggota suatu masyarakat untuk bekerja sama, berinteraksi, dan mengidentifikasikan diri".

Komunikasi yang efektif tidak akan terjalin dengan baik jika para penutur tidak memiliki referensi kebahasaan yang sama. karena peran utama dari suatu bahasa adalah pelaksanaan fungsinya sebagai alat komunikasi. Satu hal yang tidak dapat dihindari dari implementasi peran bahasa sebagai alat komunikasi dalam masyarakat adalah terjadinya kontak bahasa. Kontak bahasa yang dimaksud adalah bertemunya dua bahasa atau lebih dalam suatu proses komunikasi sosial. (Jendra, 2001: 67).

Ungkapan diatas menegaskan bahwa kontak bahasa merupakan kondisi sosiolinguistik yang kemungkinan dapat terjadi dengan cara spontan ketika seorang penutur mengganti kode bahasa yang sedang digunakan dalam suatu proses komunikasi. Sedangkan Penggantian kode bahasa dapat terjadi baik secara keseluruhan, atau hanya memasukkan unsur bahasa lain dalam bahasa yang sedang digunakan, atau pergantian variasi sebuah bahasa. Hal tersebut dilatar belakangi oleh suatu alasan tertentu yang diantaranya adalah terjalinnya komunikasi lebih mudah untuk dimengerti oleh mitra tutur.

Kridalaksana (1984:102) mejelaskan kode sebagai "(a) Lambang atau sistem ungkapan yang dipakai dalam menggambarkan makna tertentu, dan bahasa manusia adalah sejenis kode; (b) sistem bahasa dalam suatu masyarakat; (c) variasi tertentu dalam bahasa". Dapat difahami lebih sederhana seperti yang dijelaskan Wardhaugh (1988) bahwa, kode adalah semacam sistem yang dipakai dua orang atau lebih untuk berkomunikasi (Rahardi, 2001: 22).

Alih kode adalah salah satu aspek ketergantungan bahasa dalam masyarakat bilingual atau multilingual. Dengan maksud bahwa dalam masyarakat bilingual atau multilingual kemungkin besar sesekali seorang penutur menggunakan berbagai kode dalam tindak tuturnya sesuai dengan situasi dan berbagai aspek yang melingkupinya. Menurut KBBI (2007), alih kode adalah penggunaan bahasa lain atau variasi bahasa lain untuk menyesuaikan diri dengan peran atau situasi lain ataupun dikarenakan adanya partisipan yang lain.

Sedangkan menurut Jendra (2001) alih kode adalah situasi di mana seorang pembicara dengan sengaja mengganti kode bahasa yang sedang ia gunakan karena suatu alasan. Hal itu disepakati 
Mubasyiroh

Pietro (1977) bahwa code switching is the use of more than one language by communicants in the execution of a speech act (Jendra, 2001: 74).

Appel (dalam Chaer dan Agustina: 2004) mengemukakan bahwa alih kode merupakan suatu gejala peralihan pemakaian bahasa karena berubahnya situasi. Gejala peralihan bahasa yang dimaksud tentulah melibatkan lebih dari dua bahasa yang digunakan dalam tindak komunikasi.

Hymes (dalam Chaer dan Agustina: 2004) menyatakan lain tentang alih kode seperti halnya dikemukakan oleh Appel yang menyatakan bahwa peristiwa alih kode itu terjadi antarbahasa. Namun, Hymes menyatakan bahwa alih kode itu bukan hanya terjadi antarbahasa, melainkan dapat terjadi pula antara ragam-ragam atau gaya-gaya yang terdapat di dalam satu bahasa. Secara lengkapnya, Hymes (dalam Chaer dan Agustina, 2004: 108), mengatakan "code switching has become a common term for alternate us of two or more language, varieties of language, or even speech styles".

Berdasarkan beberapa definisi tersebut, dapat disimpulkan bahwa Alih kode terjadi dengan masingmasing bahasa yang digunakan masih memiliki otonomi masing-masing, dilakukan dengan sadar dan disengaja yang dikarenakan oleh sebab-sebab tertentu

Alih kode dan campur kode bukanlah bentuk kesalahan berbahasa yang disebabkan lemahnya penguasaan penutur terhadap bahasa yang digunakan. Hal ini sesuai dengan pendapat Muharram (2008) yang menyatakan bahwa "alih kode bukanlah merupakan suatu kebetulan atau terjadi secara sembarang, dan bukan pula merupakan kekacauan pemakaian bahasa seperti banyak dikatakan orang, melainkan ditentukan oleh berbagai keadaan sosial dan situasional serta syarat dengan makna sosial".

Pada umumnya kecenderungan alih kode dan campur kode lebih besar kemungkinannya untuk terjadi dalam wacana lisan. Namun, alih kode dan campur kode dapat juga terjadi pada wacana tulis yang dilatarbelakangi oleh sebab-sebab tertentu, misalnya tidak adanya ungkapan yang tepat dalam bahasa yang dipakai itu, sebagai contoh "mantab/mantul" dan sebab-sebab lainnya. Seorang pembelajar bahasa misalnya, ia mewarnai percakapannya karena keterbatasan kemampuan mereka sehingga mereka menulisnya dengan menghadirkan alih kode dan campur kode dalam dialog Bahasa arab yang ditulis dengan huruf pegon.

Diantara ciri alih kode adalah (a) adanya aspek ketergantungan bahasa di dalam masyarakat multilingual. Artinya di dalam masyarakat multilingual hampir tidak mungkin seorang penutur menggunakan satu bahasa secara mutlak tanpa sedikitpun memanfaatkan bahasa lain. (b) menurut Suwito (1985: 69) bahwa, "Pemakaian dua bahasa atau lebih dalam alih kode ditandai oleh: 1) masingmasing bahasa masih mendukung fungsi-fungsi tersendiri sesuai dengan konteksnya, dan 2) fungsi masing-masing bahasa isesuaikan dengan situasi yang relevan dengan perubahan kodenya .

Hymes (dalam Rahardi: 2001) membagi alih kode menjadi dua yaitu 1. alih kode internal (internal code switching), yaitu terjadi antar bahasa daerah dalam satu bahasa nasional, antar dialek dalam satu bahasa daerah, atau antara beberapa ragam dan gaya yang terdapat dalam suatu dialek. 2. alih kode eksternal (external code switching) yaitu apabila yang terjadi adalah antara bahasa asli dengan bahasa asing.

Selanjutnya, berbicara tentang arah alih kode, Poedjosoedarmo (1976) mengemukakan bahwa kode dapat beralih dari satu varian ke varian yang lain. Peralihan dapat menuju dari yang paling formal ke yang paling informal, dari yang paling menghormat ke yang paling tak menghormat, dari yang amat lengkap ke arah yang paling ringkas, dari dialek yang kurang dikuasai ke dialeknya sendiri, dan sebaliknya.

Bentuk alih kode dapat dipandang dari dua segi, yaitu dari segi bentuk bahasa yang digunakan dan dari segi hubungan antarbahasa yaitu a. Bentuk bahasa komunikasi yang digunakan terdapat, 1) Bentuk bahasa formal. Poedjosoedarmo (1976) mengemukakan bahwa bahasa yang digunakan dalam ragam formal biasanya penuh dan runtut, sesuai dengan tuntutan-tuntutan kaidah tata bahasa yang berlaku. 2) Bentuk bahasa informal Bentuk bahasa informal sering digunakan dalam ragam akrab. 
Martin Joos (dalam Chaer dan Agustina: 2004) mengemukakan bahwa ragam akrab digunakan oleh para penutur yang sudah mempunyai hubungan yang akrab, seperti pembicaraan antar anggota keluarga, antarteman karib, dan lain-lain.

Hubungan guru-siswa dapat dikatakan memiliki hubungan yang akrab. Hal itu dikarenakan mereka telah mampu menjalin hubungan berkomunikasi yang cukup lama meskipun hanya dalam proses belajar mengajar di kelas.

Pembahasan tentang alih kode selalu diikuti dengan pembahasan campur kode. Karena kedua gejala tersebut seringkali terjadi secara bersamaan dalam sebuah peristiwa sosiolinguistik. Kachru mendefinisikan campur kode sebagai pemakaian dua bahasa atau lebih dengan saling memasukkan unsur-unsur bahasa yang satu ke dalam unsur bahasa yang lain secara konsisten (Suwito, 1985: 89).

Dalam KBBI (2007), campur kode adalah penggunaan satuan bahasa dari satu bahasa ke bahasa yang lain untuk memperluas gaya bahasa ataupun ragam bahasa, pemakaian kata, klausa, idiom, sapaan, dan lain sebagainya; dan interferensi. Secara sederhana, campur kode diartikan sebagai suatu gejala pencampuran pemakaian bahasa karena berubahnya situasi tutur. Terjadinya Peristiwa campur kode disebabkan seorang penutur bahasa, misalnya bahasa Indonesia memasukkan unsu-runsur bahasa daerah atau memasukkan Bahasa Arab dengan bahasa Indonesianya. Dengan kata lain, seseorang berbicara dengan kode utama Bahasa Arab yang mempunyai fungsi keotonomiannya, sedangkan kode Bahasa indonesia terlibat dalam kode utama tersebut merupakan serpihan-serpihan saja tanpa fungsi atau keotonomian sebagai sebuah kode (Aslinda dan Syafyahya: 2007).

Chaer dan Agustina (2004: 114) menyatakan, "Dalam campur kode ada sebuah kode utama atau kode dasar yang digunakan dan memiliki fungsi dan keotonomiannya, sedangkan kode-kode lain yang terlibat dalam peristiwa tutur itu hanyalah berupa serpihan-serpihan (pieces) saja, tanpa fungsi atau keotonomian sebagai sebuah kode".

Campur kode (code mixing) terjadi apabila seorang penutur menggunakan suatu bahasa secara dominan, mendukung suatu tuturan disisipi dengan unsur bahasa lainnya. Hal ini biasanya berhubungan dengan karakteristik penutur, seperti latar belakang sosial, tingkat pendidikan, serta rasa keagamaan. Biasanya ciri menonjolnya berupa kesantaian atau situasi informal, namun bisa juga terjadi karena keterbatasan bahasa, ungkapan dalam bahasa tersebut tidak ada padanannya, sehingga ada keterpaksaan menggunakan bahasa lain, walaupun hanya mendukung satu fungsi (Azhar, dkk. 2011: 16-17).

Berdasarkan hubungan kekerabatan antara bahasa sumber dan bahasa sasaran, Indra (2008) mengklasifikasikan campur kode menjadi tiga jenis, yaitu campur kode ke dalam (inner code-mixing), campur kode ke luar (outer codemixing), dan campur kode campuran (hybrid code mixing).

Dalam sebuah kalimat, pastilah terdapat unsur-unsur (konstituen) pembentuk kalimat tersebut. Unsur-unsur pembentuk kalimat yang dimaksud dapat berupa kata, frasa, ataupun klausa. Setiap unsur tersebut dapat dibedabedakan berdasarkan kategori, fungsi, ataupun perannya dalam kalimat tersebut.

Beberapa jenis kategori yang dapat menjadi unsur dalam sebuah kalimat adalah nomina (kata benda), pronomina (kata ganti), verba (kata kerja), adjektiva (kata sifat), numeralia (kata bilangan), adverbia (kata keterangan), dan kata tugas seperti preposisi (kata depan), konjugasi (kata penghubung), dan partikel (Arifin dan Junaiyah: 2008).

Hal tersebut juga sesuai dengan Brice dan Absalom (dalam Anderson dan Brice: 1999) lewat observasinya yang dituangkan dalam sebuah arikel yang berjudul "Code Mixing in a Young Bilingual Child"yang membahas tentang campur kode yang terjadi pada anak-anak, mengelompokkan bentuk campur kode yang dapat diamati berdasarkan unsur-unsur sintaksis atau unsur pembentuk suatu kalimat. Bentuk campur kode yang dimaksud dibedakan berdasarkan kategorisasinya yang meliputi: nomina yang terdapat pada subjek maupun objek, verba, frase verba, frase berpreposisi, artikel, dan kata sifat.

Alih kode dan campur kode merupakan fenomena sosiolinguistik yang memiliki kemiripan. Oleh karenanya, faktor-faktor pendorong terjadinya kedua peristiwa tersebut juga sulit dibedakan dan tidak jarang tumpang tindih. Beberapa ahli pun memberikan faktor-faktor tersebut secara bervariasi. 
Jendra (2001:74) menyatakan," Terdapat beberapa alasan mengapa seseorang dwibahasawan melakukan alih kode. Beberapa alasan tersebut diantaranya adalah mengutip pendapat seseorang, penegasan identitas kelompok atau solidaritas, masuk atau keluarnya seseorang dari suatu percakapan, menaikkan status social, menunjukkan keahlian berbahasa". Menurut Indra (2008: 36) dalam penelitiannya mengklasifikasi faktor-faktor yang mendorong terjadinya campur kode. Secara garis besar faktor pendorong terjadinya campur kode dibedakan menjadi dua, yaitu (1) ekstralinguistik dan (2) intralinguistik.

Faktor ekstralingustik dipengaruhi oleh hal-hal di luar kebahasaan. Misalnya, terkait dengan tujuan pembicaraan, situasi pembicaraan, tingkat pendidikan, status sosial, lawan bicara, dan sifat pembicaraan.

Faktor ekstralingustik bisa juga muncul dari adanya keinginan penutur untuk menjelaskan, menyatakan prestise, melucu, menggunakan bahasa yang bermakna kias, dan sebab-sebab lainnya. Sedangkan Faktor intralingustik berkaitan dengan hal-hal yang ada dalam bahasa itu sendiri. Misalnya, tidak adanya leksikon dari bahasa asli untuk konsep-konsep tertentu, leksikon bahasa asli belum atau tidak mewahanai kosep yang dimaksud dalam bahasa lain, dan sebab-sebab lainnya.

Sementara itu, Aslinda dan Syafyahya (2007) mengemukakan bahwa ciri yang menonjol dalam peristiwa campur kode adalah terjadi pada ragam kesantaian atau situasi informal. Dalam situsi berbahasa formal, sangatlah jarang terjadi campur kode dalam peristiwa tuturnya. Kalaupun ada peristiwa campur kode dalam keadaan tersebut, hal itu dikarenakan tidak adanya kata atau ungkapan yang tepat untuk menggantikan bahasa yang sedang dipakainya. Sehingga perlu memakai kata ataupun ungkapan dari bahasa daerah atau bahkan bahasa asing (Nababan: 1984).

Persamaan alih kode dengan campur kode adalah bahwa kedua peristiwa. Ini lazim terjadi di dalam masyarakat multilingual dalam menggunakan dua bahasa atau lebih. Senada dengan Hill dan Hill (dalam Chaer dan Agustina: 2004) mengatakan bahwa tidak ada perbedaan antara alih kode dan campur kode. Hal tersebut berdasarkan pada penelitian mereka mengenai masyarakat bilingual bahasa Spanyol dan Nahuali di kelompok Indian Meksiko. Chaer dan Agustina (2004) mengatakan bahwa kesamaan yang ada antara alih kode dan campur kode adalah digunakannya dua bahasa atau lebih dalam peristiwa tutur, atau dua varian dari sebuah bahasa di dalam satu masyarakat tutur. Peristiwa alih kode maupun peristiwa campur kode dapat terjadi dalam suatu perubahan bahasa atau kode komunikasi antar penutur atau di dalam penutur tunggalnya

Namun, terdapat perbedaan yang cukup nyata dari kedua fenomena ini. Alih kode terjadi dengan masing-masing bahasa yang digunakan masih memiliki otonomi masing-masing, dilakukan dengan sadar dan disengaja yang dikarenakan oleh sebab-sebab tertentu.

Lain halnya dengan campur kode. Campur kode terjadi dimana sebuah kode utama atau kode dasar yang digunakan memiliki fungsi dan otonomi. Kode yang lain yang terlibat dalam penggunaan bahasa tersebut hanyalah berupa serpihan (pièces) saja, tanpa fungsi dan otonomi sebagai sebuah kode. Unsur bahasa yang lain hanya disisipkan pada kode utama atau kode dasar. Sebagai contoh penutur menggunakan bahasa Indonesia dalam tindak komunikasinya yang menyisipkan unsur bahasa asing (bahasa Inggris ataupun bahasa Prancis), sehingga tercipta bahasa Indonesia kebaratbaratan.

Dapat disimpulkan apabila seseorang menggunakan suatu kata ataupun frasa dari satu bahasa, maka seseorang tersebut telah melakukan campur kode. sedangkan suatu bahasa dan klausa itu disusun menurut struktur bahasa lain, maka peristiwa yang terjadi adalah peristiwa alih kode.

\section{ANALIAIS DAN PEMBAHASAN}

Alih kode dan campur kode bahasa Arab (studi kasus percakapan whatsapp mahasiswa fakultas SAINTEK UIN MALIKI Malang) melibatkan pemakaian dua bahasa, yakni: bahasa Arab dan bahasa Indonesia yang ditulis dalam arab pegon.

Berdasarkan analisis yang telah dilakukan temuan pokok terkait dengan data alih kode dan campur kode berikut ini; 
1. Alih Kode

a. Alih kode berdasarkan bentuk bahasa komunikasi yang digunakan:

Alih kode berdasarkan bentuk bahasa yang digunakan dibagi menjadi dua yaitu Bahasa Formal dan Bahasa informal.

1) Bahasa Formal

Dalam Alih kode berdasarkan bentuk bahasa yang digunakan diantaranya Bahasa Formal terdapat percakapan pada informasi dalam grup whatsapp mahasiswa fakultas SAINTEK UIN MALIKI Malang berikut ini:
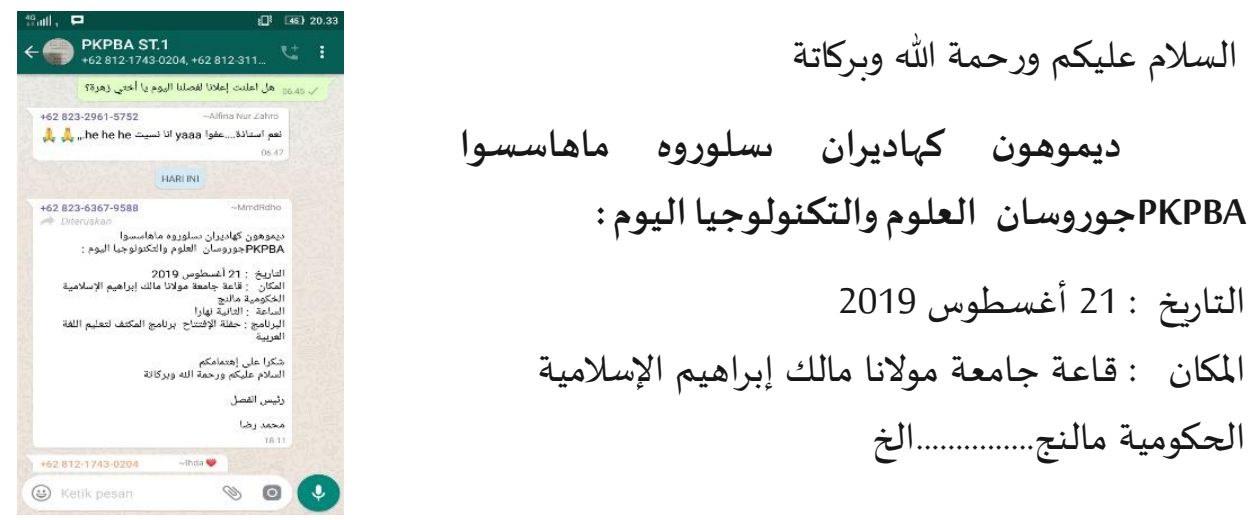

Terdapat kalimat ديموهون كهاديران سسلوروه ماهاسسوا PKPBA جوروسان "dimohon kehadiran seluruh mahasiswa PKPBA jurusan" yang ditulis dalam Bahasa Indonesia tapi bentuk tulisan pegon

2) Bahasa informal

Dalam Alih kode berdasarkan bentuk bahasa yang digunakan diantaranya Bahasa informal terdapat percakapan dalam grup whatsapp mahasiswa fakultas SAINTEK UIN MALIKI Malang berikut ini:

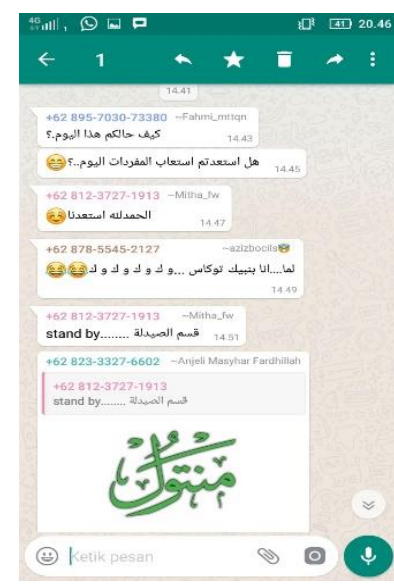

Dari paparan percakapan disamping terdapat "percakapan peralihan bahasa dari bahasa Aeab ke bahasa Indonesia yang ditulis dengan pegon

ana banyak tugas"

\section{Campur Kode}

Sedangkan Bentuk campur kode meliputi dua sisi. Diantaranya dilihat dari segi unsur sintaksis dan katagorisasi kata.

\section{a. unsur sintaksis}

Dalam Bentuk campur kode pada unsur sintaksis terdapat pada kata dan frasa

1) unsur sintaksis terdapat pada kata

Dalam unsur sintaksis ditemukan bentuk campur kode pada percakapan mahasiswa fakultas SAINTEK UIN MALIKI Malang dalam grup sebagai berikut: 


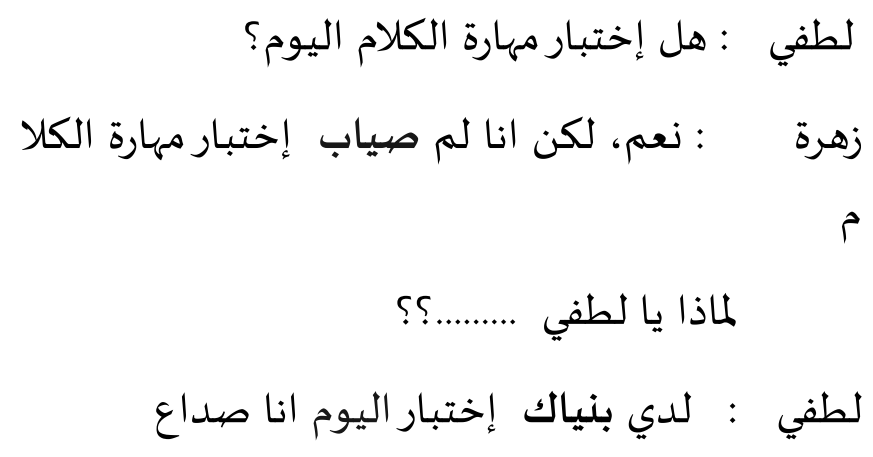

Dari paparan percakapan campur kode pada unsur sintaksis, para penutur dwibahasawan ArabIndonesia bentuk campur kode yang terdapat pada kata. صبياب dan بنياك

2) unsur sintaksis terdapat pada frase

Dalam unsur sintaksis ditemukan bentuk campur kode pada percakapan mahasiswa fakultas SAINTEK UIN MALIKI Malang dalam grup sebagai berikut:

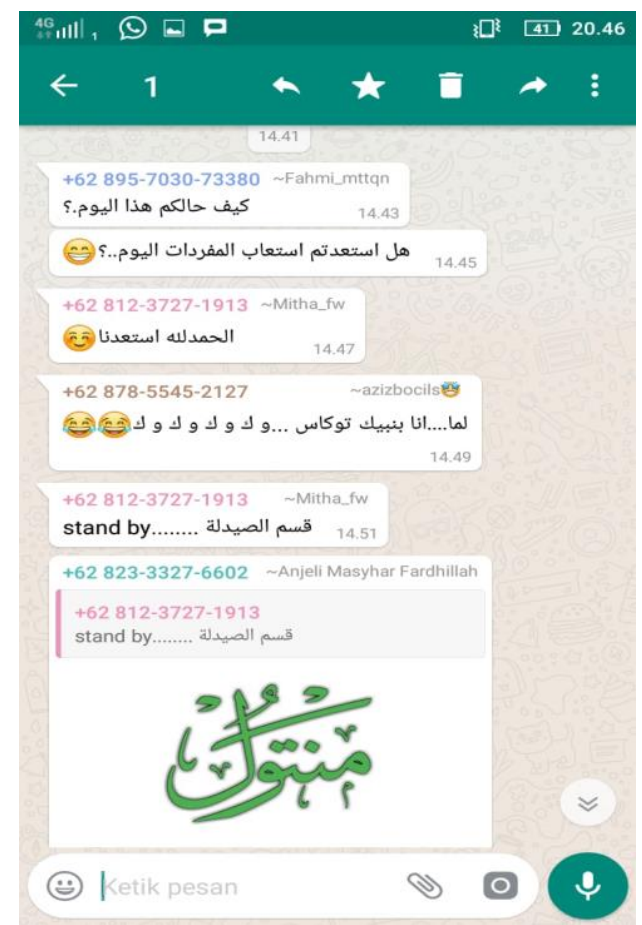

Dari paparan percakapan campur kode pada unsur sintaksis, para penutur dwibahasawan Arabindonesia bentuk campur kode yang meliputi frasa. Terdapat pada منتول (mantul)

\section{b. kategorisasi kata}

Dalam kategorisasi kata ditemukan bentuk campur kode pada percakapan mahasiswa fakultas SAINTEK UIN MALIKI Malang dalam grup whatsapp berikut ini: 
1) aumeralia

$$
\begin{aligned}
& \text { اهدا من تسكن فى مبنى فاطمة الزهرة؟ } \\
& \text { نيتا : : أنا.. لماذا؟. } \\
& \text { اهدا فى أي طبقة تسكنين؟ } \\
& \text { أنيتا أسكن فى الطبقة الثانية } \\
& \text { نيتا : ها ..... الطبقة ياغ ك دلافان؟ } \\
& \text { اهدا : الثانـة } \\
& \text { نيتا إخبري آنجيل أنا أهاتفها ..... }
\end{aligned}
$$

Dari paparan percakapan pada mahasiswa fakultas SAINTEK UIN MALIKI Malang diatas, terdapat Bentuk campur kode pada unsur kategorisasi kata, yaitu numeralia (Numeralia Tingkat) pada kata ياغ ك دلافان( yang ke delapan)

2) Pronominal

Dalam kategorisasi kata terdapat bentuk campur kode pada mahasiswa fakultas SAINTEK UIN MALIKI Malang dalam grup whatsapp berikut ini:

$$
\text { عزيهن }
$$

Dari paparan percakapan pada mahasiswa fakultas SAINTEK UIN MALIKI Malang diatas, terdapat Bentuk campur kode pada unsur kategorisasi kata Pronominal (kata tanya ) pada kata برافا dan daافا

3) Preposisi

Dalam kategorisasi kata terdapat bentuk campur kode pada percakapan mahasiswa fakultas SAINTEK UIN MALIKI Malang dalam grup whatsapp berikut ini:

$$
\begin{aligned}
& \text { انيك : ديمانا تتعلمون اليوم؟ الفصل فارغ؟ } \\
& \text { دني : نتعلم خارج الفصل }
\end{aligned}
$$

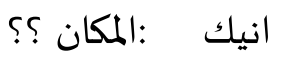

$$
\begin{aligned}
& \text { دني : ديسمبغ غازببو } \\
& \text { انيك : : شكرا : دان } \\
& \text { انيك : أنا ذاهبة هناك }
\end{aligned}
$$


Dari paparan percakapan pada mahasiswa fakultas SAINTEK UIN MALIKI Malang diatas, terdapat Bentuk campur kode pada unsur preposisi pada kata هيمانا ,ديسمبغ , هناك SA

4) Nomina (kata benda)

Dalam kategorisasi kata terdapat bentuk campur kode pada percakapan mahasiswa fakultas SAINTEK UIN MALIKI Malang dalam grup whatsapp berikut ini:

$$
\text { هلدا }
$$

Dari paparan percakapan pada mahasiswa fakultas SAINTEK UIN MALIKI Malang diatas, terdapat Bentuk campur kode pada unsur Nomina pada kata باجو

5) verba, (Kata kerja)

Dalam kategorisasi kata terdapat bentuk campur kode pada percakapan mahasiswa fakultas SAINTEK UIN MALIKI Malang dalam grup whatsapp berikut ini:

$$
\begin{aligned}
& \text { رتنا : من في الفصل الآن؟ }
\end{aligned}
$$

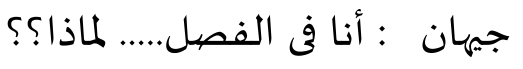

$$
\begin{aligned}
& \text { رتنا : لو سمحتم خذي كشف الحضور }
\end{aligned}
$$

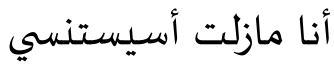

$$
\begin{aligned}
& \text { جيهان :اين أنا أكان امبيل؟؟ اسل }
\end{aligned}
$$

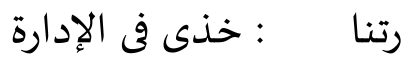

$$
\begin{aligned}
& \text { جيهان : نعم..... }
\end{aligned}
$$

Dari paparan percakapan pada mahasiswa fakultas SAINTEK UIN MALIKI Malang diatas, terdapat Bentukcampur kode pada unsur (Kata kerja) امبيل

6) Adjektiva( kata sifat)

Dalam kategorisasi kata terdapat bentuk campur kode pada percakapan mahasiswa fakultas SAINTEK UIN MALIKI Malang dalam grup whatsapp berikut ini:

$$
\begin{aligned}
& \text { فاز لمن هذا الكتاب المتروك؟ } \\
& \text { نابل : هل هناك الإسم؟ : من هن } \\
& \text { فاز : ليس هناك الإسمى } \\
& \text { نابل :علامات الكتاب؟ } \\
& \text { فاز : الكتاب بارو، وباغوس } \\
& \text { نابل : احمل فقد أولا، وغدا احمل في الحصية الأولى }
\end{aligned}
$$

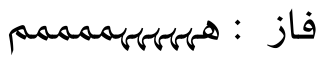


Dari paparan percakapan pada mahasiswa fakultas SAINTEK UIN MALIKI Malang diatas, terdapat Bentuk campur kode pada unsur Adjektiva (kata sifat) بارو، وباغوس

7) adverb (kata keterangan)

Dalam kategorisasi kata terdapat bentuk campur kode pada percakapan mahasiswa fakultas SAINTEK UIN MALIKI Malang dalam grup whatsapp berikut ini:

$$
\begin{aligned}
& \text { آنجل : إخوة... كبف نذهب إلى المطعم؟ }
\end{aligned}
$$

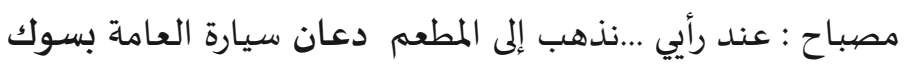

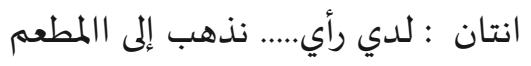

$$
\begin{aligned}
& \text { دعان جو كار go car } \\
& \text { آنجل : ماشيا على الأقدام } \\
& \text { مصباح : و ك وك وك وك عكيا } \\
& \text { آنجل : هل المكان جؤوه داري الجامعة ؟؟؟ }
\end{aligned}
$$

Dari paparan percakapan pada mahasiswa fakultas SAINTEK UIN MALIKI Malang diatas, terdapat Bentuk campur kode pada unsur adverb (kata keterangan) pada:

go car دعان ....... بسوك ، جؤوه داري ، دعان جو كار

Sedangkan Faktor-faktor alih kode dan campur kode percakapan pada mahasiswa fakultas SAINTEK UIN MALIKI Malang diatas meliputi: a)hubunganpenutur dengan mitra tutur, b) perubahan situasi dari formal ke informal atau kebalikannya. c) perubahan topik pembicaraan. d)latar belakang Pendidikan dan tingkat kemampuan

\section{KESIMPULAN}

Dalam kehidupan bermasyarakat tidak bisa lepas dari fenomena dwibahasa untuk memenuhi salah satu kebutuhan sosial manusia, terutama pembelajar yang sedang melakukan pembelajaran Bahasa asing sebagai kosentrasi keilmuan akan terjadi alih kode atau campur kode.

Peristiwa campur kode adalah Apabila seseorang menggunakan satu kata atau frase dari satu Bahasa. Peristiwa alih kode yaitu apabila satu klausa jelas-jelas mempunyai struktur gramatikal satu bahasa, dan klausa berikutnya disusun menurut struktur gramatikal Bahasa lain.

Dari penelitan ini dihasilkan temuan bahwa: 1) bentuk alih kode meliputi dua hal. Dilihat dari segi: a) bahasa yang digunakan untuk berkomunikasi, ditemukan bentuk alih kode yang meliputi: formal "bahasa sesuai dengan kaidah bahasa arab" dan informal "bahasa yang tidak sesuai kaidah Bahasa Arab". Dilihat dari segi: b) hubungan antar bahasa, terdapat bentuk alih kode yang meliputi: bahasa Arab ke bahasa Indonesia dan bahasa indonesia ditulis dalam kata arab atau pegon. 2) Bentuk campur kode meliputi dua sisi. Dilihat dari segi: a) unsur sintaksis, ditemukan bentuk campur kode yang meliputi: kata dan frasa. Sedangkan dilihat dari segi: b) kategorisasi kata, ditemukan bentuk campur kode yang meliputi: numeralia, pronominal, preposisi, nomina, verba, adjektiva dan adverbial. 3) Faktor-faktor alih kode dan campur kode meliputi: a) hubungan penutur dengan mitra tutur, b) perubahan situasi dari formal ke informal atau kebalikannya. c) perubahan topik pembicaraan. d) latar belakang Pendidikan dan tingkat kemampuan.

Penelitian ini berjenis kualitatif dengan teknik pengumpulan data dengan cara analisis. Sedangkan data bersifat deskriptif. dengan mengambil percakapan whatsapp mahasiswa fakultas SAINTEK UIN MALIKI Malang

\section{DAFTAR PUSTAKA}

Arifin, E. Zaenal dan Junaiyah. 2008. Sintaksis: Untuk Mahasiswa Strata Satu Jurusan Bahasa atau Linguistik dan Guru SMA/SMK. Jakarta: PT Grasindo. 
Mubasyiroh

Aslinda dan Leni Syafyahya. 2007. Pengantar Sosiolinguistik. Bandung: PT Refika Aditama

Azhar, I. N. (Ed). (2011). Sosiolinguistik Teori dan Praktik. Surabaya: Lima-Lima Jaya.

Chaer, Abdul dan Leonie Agustina. 2004. Sosiolinguistik: Perkenalan Awal. Jakarta:

PT Rineka Cipta.

Kartikawati, Sulistyaning dan Hendrik Pratama. Pengaruh Penggunaan WhatsApp Messenger Sebagai Mobile Learning Terintegrasi Metode Group Investigation Terhadap Kemampuan Berpikir Kritis. JUPITER (Jurnal Pendidikan Teknik Elektro) E-ISSN: 2477-8354. Volume 2, Nomor 2, Edisi September 2017.

Hymes, Dell. 1974. Foundations in Sociolinguistics: An Ethnographic Approach. Philadelphia: University of Pennsylvania Press.

Indra, I.B.K. (2008a). Faktor Pendukung Terjadinya Campur Kode dalam Pementasan Drama Gong di Bali. Aksara, XIX (31), $35-43$.

Jendra, M.I.I. (2001). Sosiolinguistics. Yogyakarta: Graha Ilmu.

Kridalaksana, Harimurti. 1982. Kamus Linguistik. Jakarta: PT Gram

Muharram. (2008). Alih Kode. Diperoleh 11 November 2019, dari http://muharrambanget.blogspot.com

Nugroho, Adi. 2011. Alih Kode dan Campur Kode pada Komunikasi Guru-Siswa di SMA Negeri 1 Wonosari Klaten. (Skripsi Fakultas Bahasa dan Seni Universitas Negeri Yogyakarta). Yogyakarta 2011

Nababan, P. W. J. 1984. Sosiolinguistik: Suatu Pengantar. Jakarta: PT Gramedia

Poedjosoedarmo, Soepomo. 1976. Kode dan Alih Kode. Yogyakarta: Balai Penelitian Bahasa, Yogyakarta.

Rahardi, Kunjana. 2001. Sosiolinguistik, Kode, dan Alih Kode. Yogyakarta: Pustaka Pelajar

Rohmani, Siti, dkk. 2013. "Analisis alih kode dan campur kode pada novel negeri 5 menara karya ahmad fuadi". BASASTRA Jurnal Penelitian Bahasa, Sastra Indonesia dan Pengajarannya, Volume 2 Nomor 1, hal 1, ISSN 12302-6405

Suwito. (1985). Sosiolinguistik. Surakarta: UNS Press.. 